\title{
EMPLOYING HERITAGE ELEMENTS IN CONTEMPORARY ARCHITECTURE - BAZAAR MARKET AS A UNIQUE ELEMENT IN ISLAMIC ARCHITECTURE
}

\author{
Samer AL-Ratrout ${ }^{{ }^{1}} \bowtie$ (iD), Rizeq Hammad ${ }^{2}$ \\ ${ }^{1}$ Department of Architecture, Jordan University of Science and Technology, Jordan. \\ ${ }^{2}$ Department of Architecture, University of Jordan, Jordan.
}

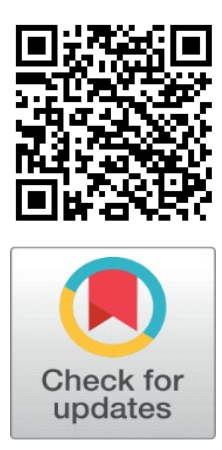

Received 9 August 2021

Accepted 21 August2021

Published 31 August 2021

\section{CorrespondingAuthor}

Samer AL-Ratrout, sratrout@gmail.com DOI

10.29121/granthaalayah.v9.i8.2021. 4187

Funding: This research received no specific grant from any funding agency in the public, commercial, or not-for-profit sectors.

Copyright: (C) 2021 The Author(s). This is an open access article distributed under the terms of the Creative Commons Attribution License, which permits unrestricted use, distribution, and reproduction in any medium, provided the original author and source are credited.

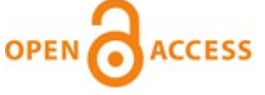

\section{ABSTRACT}

This paper examines the definition of the market and its types in terms of size and location. It is the agent in which commodities are exchanged and the processes of sale and purchase at various levels. The market developed during different time periods while malls are recently appeared to invade cities.

The research examines the bazaars in Islamic cities and their development and spread in the neighborhoods of cities. These bazaars were formed as part of the city's urban planning, its streets and buildings commensurate with the streets and buildings of the Islamic city. They developed in construction technology and architecture styles during various historical periods. They contain great architectural and construction elements and different sets of decorations and climate treatments, so that they have become unique architectural and construction museums.

A special social relationship is formed in bazaars between the seller and the buyer while the wanderer in these traditional markets enjoys the local products and the spirit of the place with its distinctive architectural work. These bazaars have been established near the Friday mosques, where shoppers visit them, and their importance has been proven over the centuries and will remain the ideal place for shopping in Islamic cities.

Keywords: Bazaar, Market, Architectural Heritage, Contemporary Architecture, Islamic Cities

\section{INTRODUCTION}

The market can be defined as the real or virtual place in which the bid and ask operations are applied; It provides an interaction between sellers and buyers in order to provide services and sell goods in exchange for barter or money Business Dictionary (2017).

The market is also known as the area in which commercial operations occur through the presence of a meeting between people and merchants in one place. Another definition of the market is the place to which goods are brought in order to be bought and sold.

The emergence of the concept of the market happened with the development of economic activities and trade operations. These activities and operations are related to the division of business where man relied on production in order to satisfy his needs within the family unit and the small community. Consequently, the productive human capabilities increased with time. This increment led to the emergence of a surplus in the economy before the use of currency, and contributed to the discovery of the concept of barter (exchange) between goods. 
In advanced stages, the emergence of commercial thought contributed to a growth in commercial exchange operations dependent on buying and selling. This growth led to the transformation of markets into a basic base in the economic system. The production became dependent on the nature of consumers' desires and the prices offered in exchange for obtaining products. This dependency resulted an evolution and helped market to reach its contemporary known state Hijazi (2017).

This paper examines traditional popular markets and their steadfastness against the contemporary emerged markets and malls. These bazaars, as traditional popular markets, are considered as heritage components of architecture that were originated thousands of years ago and are lasted and still attracting all classes of society. These markets are where the shopping processes take place within heritage buildings and genuinely adding a unique spirit that can seldomly be found in modern markets.

Previous studies of the authors have indicated other heritage elements that can be utilized in contemporary buildings or can be developed for the future to offer this nostalgic uniqueness of the times. Such elements are as ratios in openings and windows Hammad et al, (2020a), entrances to mosques Hammad et al, (2020b), and methods of rainwater collection and storage Hammad et al, (2020c).

\section{TRADITIONAL MARKETS Ayadina (2017)}

It is a commercial place, characterized by the presence of many buyers and sellers. These outlets were usually directly open to natural environment and were practically equipped with nothing. These markets were also a kind of information hub where the latest news from many regions streamed and delivered to this one place.

In the past, the markets represented a meeting point for commercial, cultural and social exchange. This indicated a prominent sign of the city's development, its large population, and the strength of its trade with the rest of its neighboring cities. Solid evidence for this indication is the Okaz market, which was considered one of the most famous Arab markets in the pre-Islamic era when most of the Arab tribes used to target, and where goods and commercial products were displayed. Besides, the markets were meeting places for reconciliation between tribes and resolving disputes and disputes.

Markets was also the place where poems were delivered and where poets used to gather, compete, and celebrate their poems to become famous and known to other Arab tribes, and for their poems to be transmitted from generation to generation.

\subsection{GEOGRAPHICAL DISTRIBUTION OF MARKETS}

This division depends on the geographical distribution of the markets and their locations. Sometimes, the market is called by the name of the region or village in which it is located. Among the types of these types of markets are:

- Village markets: are those markets located in a specific village and at a specific day. This type is known to neighboring villages for buying and selling takes place with limited quantities compared to other markets. 
- Central markets: are those markets located in the center, main, or capital city. This type is larger in size than the village markets and more active. It might be set for a specific day or be throughout the week. I might be also held in a specific place with more than one market within each region as it deals with different commodities and products.

- International markets: are those markets that usually reflect or represent a group of countries at global level, including the European Common Market, COMESA, ASEAN, or other trade blocs that represent the form of trade and markets in a specific region of the world.

\subsection{DISTRIBUTION OF MARKETS ACCORDING TO THE NATURE OF THE COMMODITY}

These are the markets categorized according to the nature of the commodities or their productive sector. these markets are divided into: Agricultural commodity markets, Consumer goods markets, and Industrial commodity markets.

\subsection{DISTRIBUTION ACCORDING TO THE NATURE AND COMPOSITION OF THE MARKET}

These are the markets categorized according to the nature and composition of the market. This includes: Local markets, Central markets, Wholesale markets, Distribution markets, Export Markets, Mixed markets, and Retail Markets.

\section{SHOPPING CENTERS (MALLS)}

Over the last few decades, large shopping centers have emerged, containing almost all kinds of goods, in addition to places of entertainment, restaurants, and even stadiums and places of physical fitness. These centers are large covered areas that are air-conditioned and security-controlled, enabling the shoppers to perform different activities, purchase most of the goods they need, order from variety of food choices socialize with friends and spend quality time with family members of all ages.

The mall usually contains large choices of local and international kinds of goods, brands, and categories. It offers wholesale and retail stores for different types of goods, such as agricultural crops and sheep, poultry and beef products. Malls are centers for all necessary house and office supplies and accessories. Such Huge markets have been spreading in most large cities around the world. Many of them are located in the same city, such as Joran capital city of Amman, which contains around 40 Malls.

These markets are an attraction for a large number of shoppers and customers who visit them for spending holidays, leisure time and social events. Most of the malls are opaque from the outside and open to the inside, so that to keep the visitor focused on the marketing products and the entertainment experience offered in these malls. Malls are considered a qualitative leap in the philosophy of shopping experience. Despite the many advantages they have, malls have some disadvantages which include:

- Leading to negative dissonance with the urban content for being largesized buildings located within the city, having huge solid facades, and 
mostly located to serve residential districts that usually possess distinctive urban character (Figure 1a).

- Disrupting local traffic due to the large number of visitors, which lead to permanent traffic challenges, especially on holidays and vacations. Heavy traffic affects the lifestyle of the surrounding areas. With malls, the once quiet streets become crowded with local traffic overflow (Figure 1a).

- Increasing the burden on the infrastructure systems, blocking the sun, wind and desired views from the neighboring areas, and disrupting urban atmosphere of residential areas (Figure 1a).

- Overloading goods and products prices as a result of high overheads on stores renting costs, costs of services like air conditioning, security systems, housekeeping and parking areas (Figure 1b).

- Negatively, affecting shoppers to rush towards global fashions and trends causing genuine public heritage and the thinking patterns of the local communities to lose individuality (Figure 1b.).

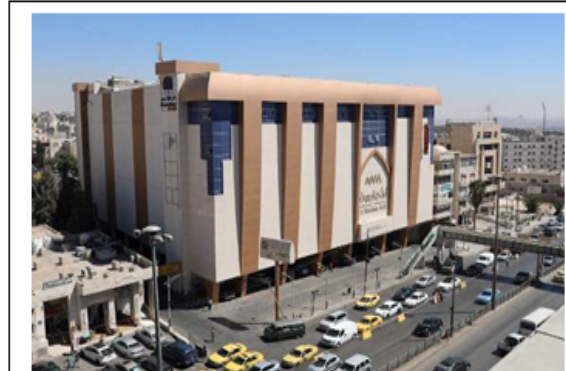

Figure (1.a.)

"Al-Mukhtar Mall", Amman, Jordan.

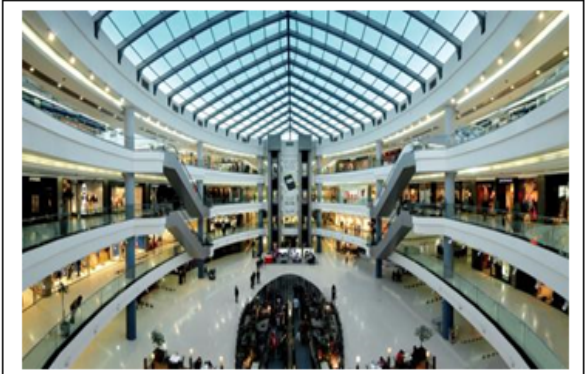

Figure (1.b.)

"City Mall", Amman, Jordan.

Figure $1(a, b)$

- Causing local community to lose traditions of identity, to miss its uniqueness of cultural individuality and to silent its local character of form and content. This is happening as a result of offering a unified character of shopping experience and process with obvious global similarities of malls shopping experience around the world with similar exhibits and purchases (Figure 2a.).

- Repelling small sellers who trade in local products by not being allowed to function inside or near these malls. This will able the mall to guarantee monopolization of products without small competitors. This causes the mall to become a place of limited layer of shoppers with expensive shopping abilities (Figure 2b.). 


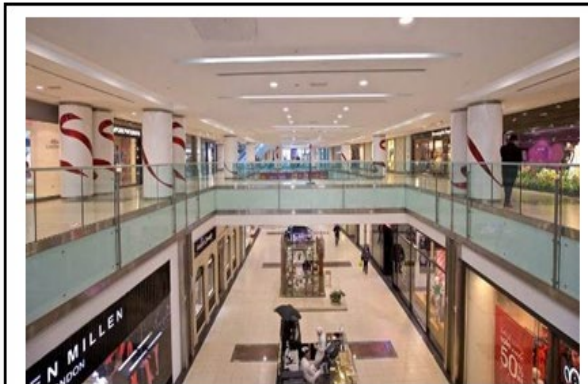

Figure (2.a.)

"Taj Mall", Amman, Jordan.

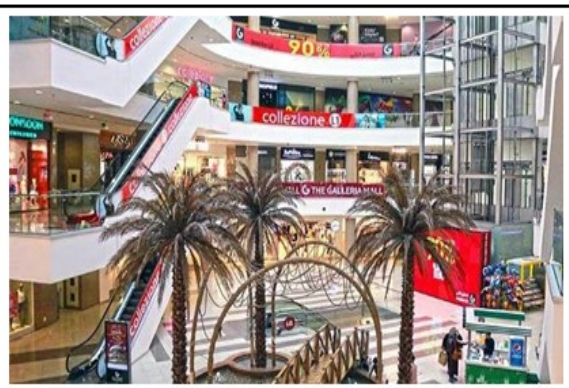

Figure (2.b.)

"Galleria Mall", Amman, Jordan.

Figure $2(a, b)$

\section{SPATIAL TRADITIONS OF BAZAAR}

Bazaar is a permanent place to offer local products for selling directly from the producer to the consumer without the commercial mediation that usually cause prices to be unjustifiably increased. It also offers fresh products for selling to consumers and often offer seasonal agricultural crops in addition to some locally made supplies.

Bazaars contain small local factories and workshops scattered in dedicated passageways that specialize in a specific category or products. Some of these products are such as leather crafts, copper products and fabrics. It is the place where the products makers and handcraft persons sell their products directly to consumers and to merchants. It also contains places for serving food and for resting areas to make it easier for the shoppers to buy their needs and spend a quality time while consuming locally prepared meals with fresh ingrediencies (Figure 3).

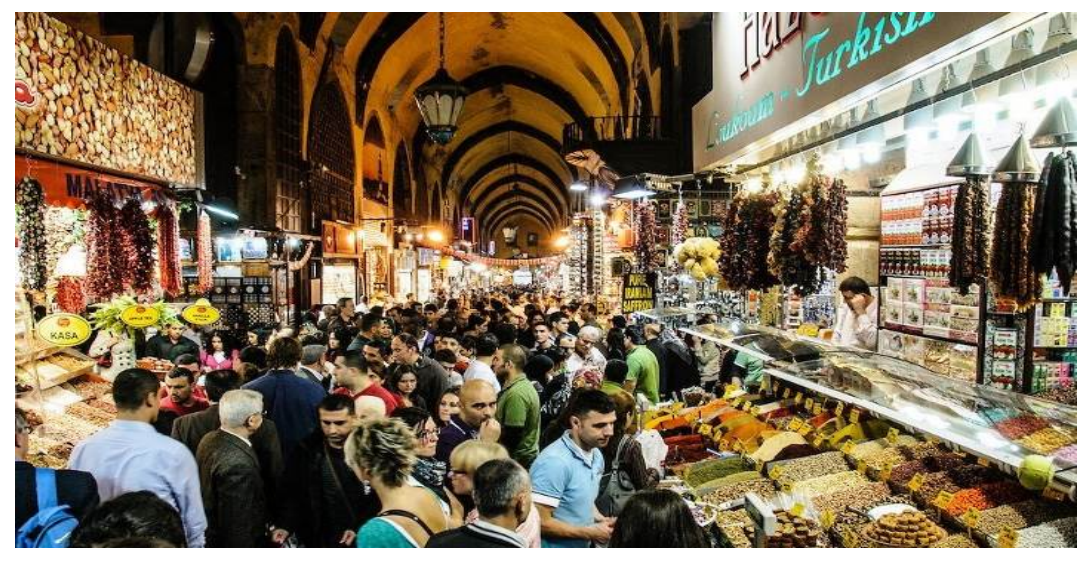

Figure 3 “Spice Bazaar”, Istanbul, Turkey

Bazaars are spread all over the Islamic world and the permanent parts of them are usually located near Friday mosques, where the public flock to them to spend the five prayers of the day and buy their needs. Examples of these bazaars are the Hamidiyeh Market in Damascus, which is located in the squares of the Umayyad Mosque (Figure 4a.). Another Example is Khan al-Khalili in Cairo, located near the Al-Azhar Mosque (Figure 4b.). 

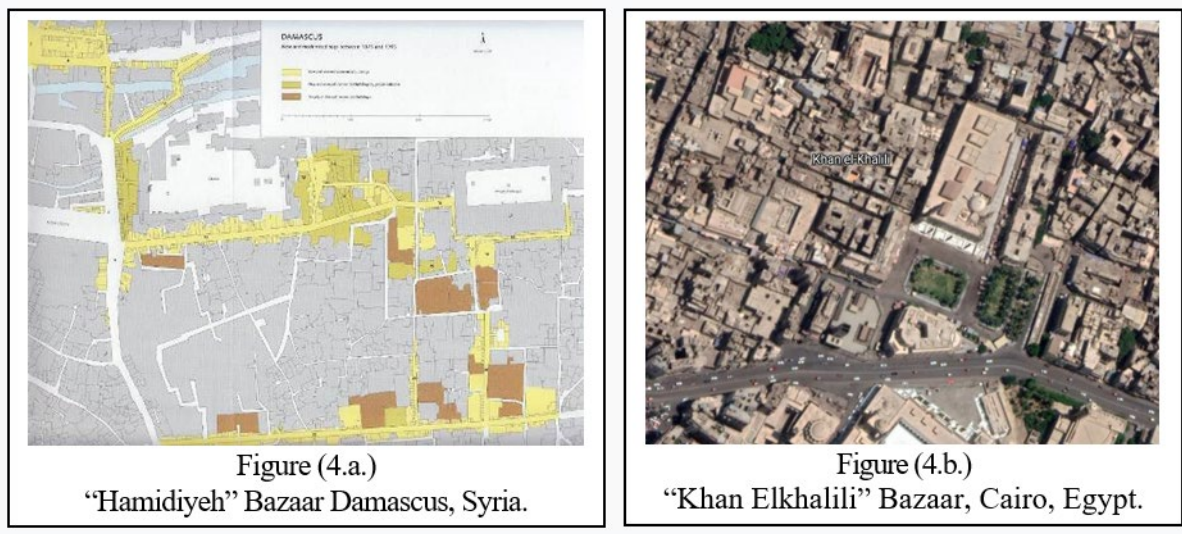

Figure $4(a, b)$

Similar bazaars are scattered all over Istanbul, Tehran, and other cities with Islamic context Temporary and seasonal markets are usually located adjacent to the permanent markets. These markets are intended to attract large number of customers and shoppers who arrive to buy fresh and local products and goods. The products are offered with affordable prices as they are retailed directly from the producer to the consumer. Through attracting large numbers of customers, these temporary seasonal markets increase the number of shoppers in the permanent central markets.

\subsection{BAZAAR URBAN MORPHOLOGY}

The most important characteristic that distinguishes bazaars from modern malls is that they are initially composed and grew with time in an organic manner. This organic formation represents an integral part of the city's original urban fabric that appeared and developed with the development of the city itself. The fabric appearance of this organic integration goes in harmony with the formation of the city and not imposed on it which prevent contradicts with the urban fabric of the city (Figure 5a.).

(Figure 5b.) of Esfahan Bazaar shows a naturally shaped extension of the bazaar as part of the city center growth where the streets stretch from the residential areas towards the bazaar. It shows also that the adjacent building blocks grew with time in harmony with the building blocks of the bazaar itself.

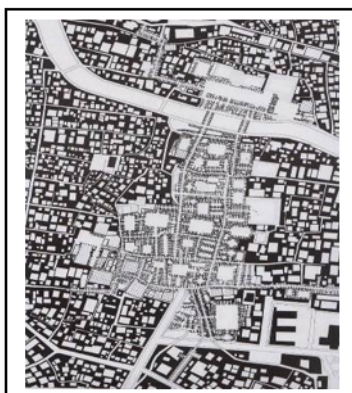

Figure (5.a.)

"Tabriz Bazaar". Tabriz.

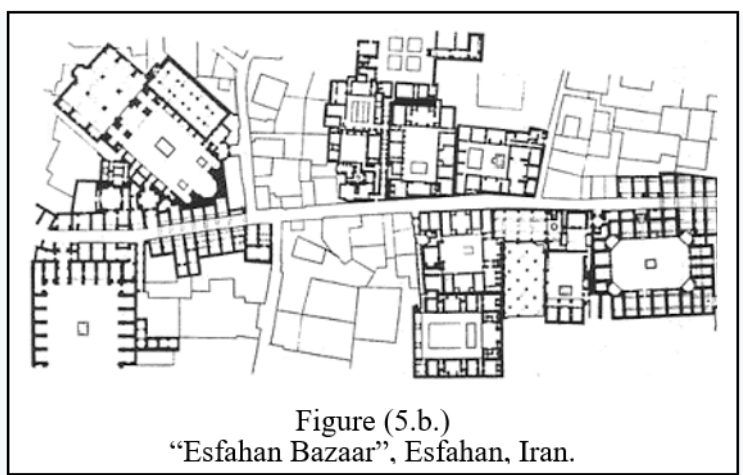

"Esfahan Bazaar", Esfahan, Iran.

Figure $5(a, b)$ 
The bazaar expands naturally with ease within the neighborhoods of the city without enforcing any harmful composition or contradiction with the distinguished urban tissue of the city. On the contrary, the modern malls usually appear as huge architectural blocks rising above the neighboring residential areas, causing traffic dilemmas and anomalous visual appearance in terms of shape, size, scale and facades (Figure 1a.).

The organically integrated appearance can also be applied to many of traditional markets, such as Al-Hamidiyeh market in the city of Damascus (Figure 4a.). This traditional market consists of main passageways leads to the Umayyad Mosque. This main passageway extends to connect many commercial lanes leading to workshops of traditional small industries and handcraft workplaces. Each of the lanes is distinguished by a specific shape. This is evident from the contextual urban planning scheme of the market. This integration represents a natural extension of the city's streets and forms a cohesive spatial relation with the neighboring residential and commercial buildings.

(Figure 4 b.) also represents the Khan al-Khalili site, which is adjacent to the AlAzhar Mosque and the Al-Husseini Mosque, and it consists of many passageways and lanes. Each of these lanes specializes in a specific workmanship and special merchandise, and it represent, as seen in the figure, an integrated and cohesive extension of the urban fabric of the old city of Cairo.

These markets are characterized by their distinguished traditional architecture that preserved its spatial identity for centuries. Until today, these markets still represent a favorite place for shoppers and researchers interested in the traditional identity of a city.

\subsection{BAZAAR INTERIOR SPATIAL FORMATION}

The spatial interior formation of the Bazaar is one of its most distinctive elements, as it consists of diverse structural elements connected to each other, reflecting the building methods and structural techniques of the era in which it was initiated (Figure 6 a.). The bazaar, with its variety of passageways and lanes, was not typically constructed as a full-scale project that was constructed in just one single period of time, but rather it spanned hundreds of years from initiation to expansion to extension. Hence, it is noted that it contains the recognized structural elements of its time. Some of these elements are longitudinal and intersecting vaults, domes, wooden corbels metal trusses, stone walls and posts, as well as wooden and metal fenders.

Different types of openings are also noticeable with their decorations and the types of stained glass recognized during the period in which a specific part of the bazaar was built.

The visitor to these bazaars usually had the chance to enjoys not only the different types of goods and products, but also the unique spatial characteristics and the various decorative elements that were utilized in their various and extended eras of construction. This spatial experience where the wanderer appreciates and enjoy observing its stunning architectural aesthetics (Figure 6 b.). 

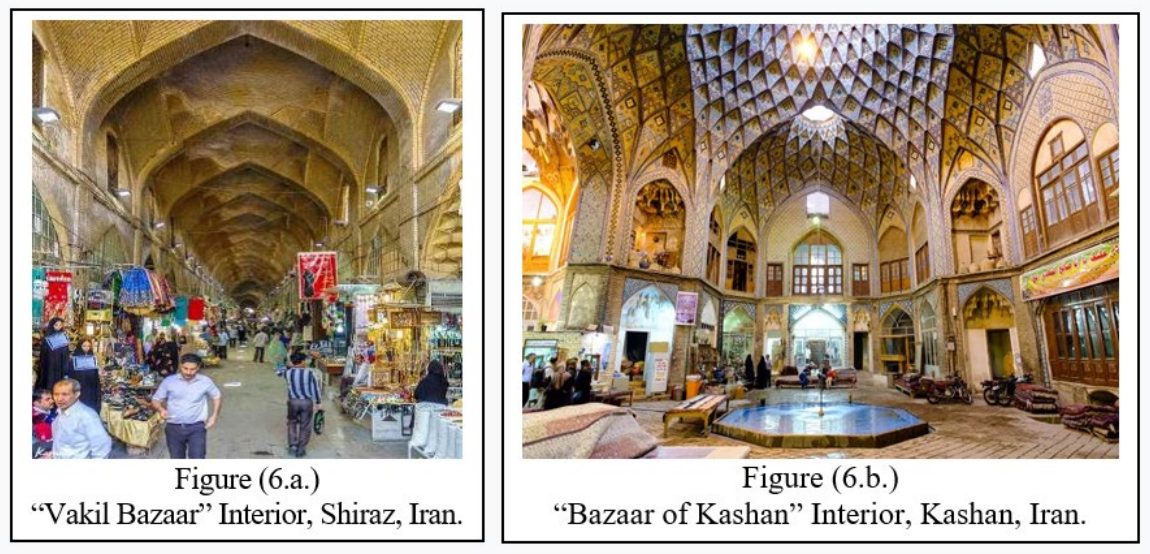

Figure $6(a, b)$

These unusual observations are not effortlessly experienced in modern constructed markets that defer the way of targeting this kind of essence and pleasure that is easily offered in bazaars. The Hitchhiker in the traditional markets finds noticeable similarities in the architectural experience of bazaars in the Middle East region. At the same time, analogous similarities can be indicated within the interior spatial formation of the bazaars, whether in Turkey, Iran, Damascus or Cairo.

When visiting bazaars, the feeling of alienation and isolation is not present. Instead, the feeling of relation and connection between bazaars, are apparently noticed despite their different location and deferent time periods of construction. Feeling of being in a strange place or country is usually not evident as the feeling of alienation that is evident in the spatial experience of modern markets (Figure 7 a.).

Similarly, the unique relationship between the wanderer in the bazaar and the merchants and sellers who encourage discussions and dialogues with the manufactures, the locations to find specific goods, the means to handcrafts and produce, and perhaps enjoy a dialogue of social, political, or religious matters and emergent news. In most cases, free tea or drinks are provided to the buyer out of courtesy and social respect. Some other times, they exchange their addresses and phone numbers to increase knowledge or to provide delivery services and other social matters that take place in the bazaar. The buyer does not feel a negative competition between neighboring stores, but rather a positive complementarity between them (Figure 7 b.).

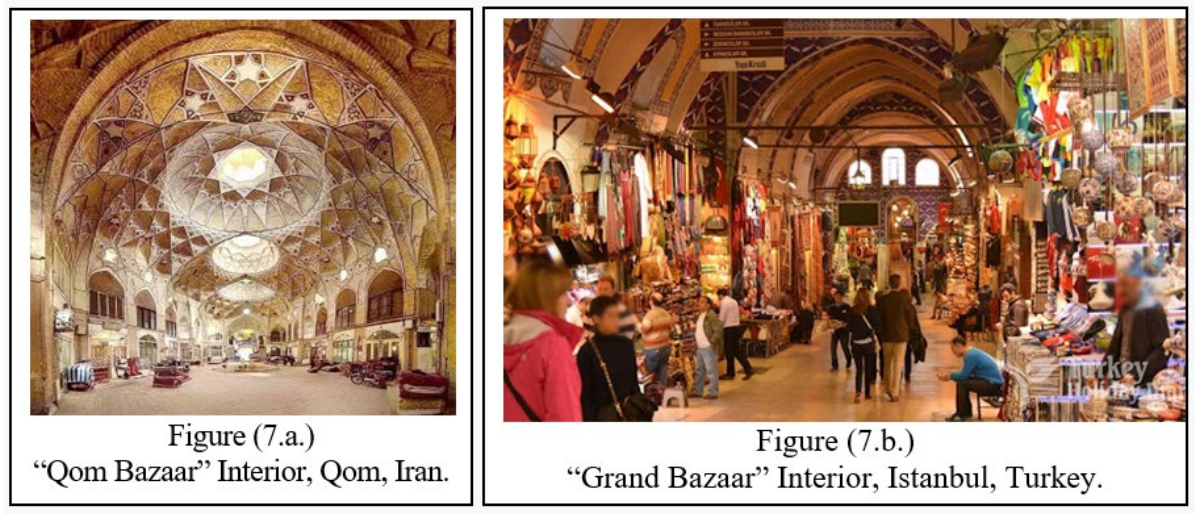

Figure 7 (a, b) 
These bazaars still exist and compete greatly with modern markets, and mostly they are more preferred to the limit that globalization that comes with contemporary markets experience may be endangered to be abandoned and replaced. As for the traditional bazaar, it is an integral part of the city fabric which contains a historical and urban heritage that spanned for centuries and is entitled to be sustained for centuries to come.

\section{SUMMARY}

This paper is part of several papers discussing several architectural heritage elements, in Islamic buildings and adapting them in new buildings. The function of these elements is still the same and are developed through different eras; such as the proportion of windows, mosques inferences, minarets, mihrabs and the traditional techniques of water harvesting in arid regions and other elements. This paper is examining here the bazaar markets in several Islamic countries, as traditional markets which are still attracting shoppers and others.

The bazaar is a special kind of commercial market that originated and developed in Islamic cities over the life of the city and was an integral part of its urban fabric and reflected the structural and architectural style of different historical periods. The bazaars in Islamic cities are similar due to the similarity of Islamic thought in buying and selling and the traditions similarity between the different Islamic cities. These bazaars are developed as part of the city fabric and integrating with city streets, building facades, materials, decorations and environment. The bazaar is considered as one of the most important elements of the architectural heritage of Islamic architecture, which is still performing its commercial function and expresses a continuous architectural heritage. It differs from the commercial thought of modern markets and malls as the visitors to these bazaars enjoy buying their needs while enjoying the architectural and construction works. These works include the types of decorations and climate treatments that have been developed over the centuries of the bazaar's life.

Bazaars are still competing with new trends of malls and new markets, as they possess wide variety of marketing goods within interiors of traditional designs and constructions surrounded by unique environments. Bazaars will continue to be the more suitable spaces for enjoying shopping and spending pleasant time for the whole family in Islamic world. They will continue also to develop, and stay sustained to remain testaments to the Islamic architectural heritage and great competitors to modern commercial markets and malls.

\section{REFERENCES}

Ayadina for businesses and projects, (2017) (March 06). Edited [Online] Available: Retrieved from https://ayadina.kenanaonline.com/

Business Dictionary (2017), [Online], (March 06,). Edited.

Hammad, R. et al, (2020a) "Employing Heritage Elements in Contemporary Architecture. Openings and Windows: The Case of Housing Buildings in Amman - Jordan, 2020, Journal of Engineering and Architecture, June 2020, Vol. 8, No. 1, pp. 1-10. Retrieved from https://doi.org/10.15640/jea.v8n1a1 
Hammad, R. et al, (2020b) "Employing Heritage Elements in Contemporary Architecture. Mosque's Gates: Case Study in Amman City - Jordan, Journal of Engineering \& Architecture, December 2020, vol. 8, No. 2, pp. 17-21. Retrieved from https://doi.org/10.15640/jea.v8n2a3

Hammad, R. et al, (2020c) "Urban Rainwater Harvesting: an approach for water Provision for Cities in Simi-Arid regions: The Case of Um Uthaina Neighborhood in Amman - Jordan", Journal of Engineering and Architecture, ISSN: 2334-2986 (Print), 2334-2994 [Online].

Hijazi, H. (2017), "The Souq" -in Arabic- Arabic Encyclopedia. [Online], (March 06). Edited. 